\title{
'Not On Our Street': New Urban Spaces of Interracial Intimacy in 1950s and 1960s New Zealand
}

\section{BRONWYN LABRUM}

In the latter part of 1960, Mrs Fitchett, from the suburb of Henderson in Auckland, New Zealand's largest city, complained to the Department of Māori Affairs (DMA) about a Māori family in her neighbourhood. She stated that she disliked the behaviour of the children when playing with rugby balls in the street and she alluded to other nuisances. The Department's district welfare officer personally investigated her complaint. Mindful of the current preoccupation with 'Māori problems' in official and popular discussions, he was worried about the ramifications not only in the local community, but also in greater Auckland. Large-scale Māori urbanization brought with it rapidly growing perceptions of social disorder and a growing Māori 'underclass'. The district welfare officer hoped to set up a street meeting of four families, including Mrs Fitchett and the Joyners. Although Mrs Fitchett thought that it would be difficult to get both Māori and European (as she described herself) to come together, three of the four households eventually met: Mrs Fitchett and two Māori families. Despite a few outbursts, the two Māori families agreed that they were at fault to some extent. The officer concurred that not all the charges could be substantiated. It was agreed that the Māori mothers in the street would investigate setting up a branch of the Māori Women's Welfare League, 'to help us promote some social action and social education', in the officer's words. Mrs Fitchett offered her services as an adviser in gardening. ${ }^{1}$

Although Mrs Fitchett's complaint was about the children, her real target was the family and, more specifically, its adult members. She objected to the presence of Māori in her neighbourhood and to Māori as Māori. This incident and its follow-up allow us a glimpse beyond the idealized form of domesticated family life in the postwar period that has been the focus of much writing. It provides a window onto lives that are lived between houses and in 'the street', whether literally - the children playing there which was, ostensibly, the basis for the complaint - or 'the street' meaning a larger entity to which 'we' (all the residents) belong and around which the reputation and behaviour reflects on everyone. It reveals tension, conflict, prejudice, and defensiveness about patterns of living that ran against majority habits and values.

Mrs Fitchett's complaint was one of hundreds which Māori welfare officers fielded about neighbourly tension and hostility from the late 1940s onwards. Such letters and investigations provide evidence that the neighbourly propinquity of suburban living in the 1950s and 1960s was a new form of racial intimacy for many. By 'intimacy' I mean a closeness that is not sexual or familial - although families are involved - but rather intimacy that is constituted through proximity, and which is not always sought by all of the parties. ${ }^{2}$ It was not only Māori who were encouraged to integrate and live 'the New Zealand way of life' by living up to the Pākehā norm. This standard was characterized by a family home in the suburbs, because home-ownership was a 'central motif in the post-war social pattern ... [and] expressed the ruling ideas about family life and childrearing, the need for privacy and space'. Housing and living patterns reflected Pākehā characteristics of 'possessive individualism, equality [and] cultural homogeneity'. ${ }^{3}$ Yet post-war New Zealand was becoming more diverse and mixed because of migration, as well as urbanization. Post-war suburban spaces therefore brought 'races' (and ethnicities) into spatial, suburban, domestic proximity, 
sometimes planned, but often the result of the vagaries of where housing was found happenstance rather than sought out intimacy.

In focusing on suburban racial intimacy, and briefly extending consideration to other ethnic groups which were also moving into New Zealand suburbs at this time, the discussion moves the wider scholarship beyond its predominant focus on the imperial past and colonial encounters. ${ }^{4}$ This essay deliberately brings our gaze forward in time to consider this theme in the mid-twentieth century, shifting from the colonial to the post-colonial period, and in the context of nation rather than empire. ${ }^{5}$ It argues that the character of post-war suburban racial intimacy was influenced by government policy in the 1950s and 1960s, in an era that was moving from assimilation to integration (as well as being part of wider lived experience).

\section{Considering the material and the visual}

Conventional archival sources dominate scholarship on the relationship between sex, race and colonialism. In contrast, my exploration of post-war patterns of interracial intimacy focuses on how material and visual sources provide another way to look at this phenomenon and understand it. It also demonstrates how those sources formed part of the contemporary imagining of that new intimacy, something Anna Haebich has identified in her research on assimilation of Aboriginal peoples in Australia. ${ }^{6}$ It is interesting that the 'material' circumstances of various forms of historical intimacy are often invoked by scholars in this field. Indeed the metaphor of 'fabric' is frequently used, as in the 'connective fabric of empire' or the 'full fine fabric of colonial lives'. But what does this mean, on the ground or in the neighbourhood, and in the midtwentieth century? Recent scholarship on historical material culture has called for work that goes beyond consumption and the creation of meaning and identities through objects. It urges historians to not stop at the domestic doorstep but to go out onto the section or into the street and beyond. Taking this approach, they suggest, would reconnect private and public and provide a bridge between histories of politics and material culture. ${ }^{8} \mathrm{~A}$ focus on practices, rather than simply things, would also capture 'ordinary', everyday practices such as gardening, washing, listening to the radio, or practising hobbies. This would extend to material practices of keeping house, neighbourliness of various kinds, and children's play in the streets.

Visual sources are, on the whole, generally overlooked by historians, which is surprising given how plentiful they are, especially for the twentieth century. Images of many kinds can help to excavate 'practices of looking', which reveal, in a raft of ways and through different angles, the social construction of vision and visuality. ${ }^{9}$ Mrs Fitchett keeping her eye on the street and the garden, what she sees and also does not see, alerts us to the way that practices of looking can be used as a theoretical approach and method to reflect upon. The images used in this chapter demonstrate how neighbourhood and domestic suburban intimacy is designed and imagined, and are as much about the socially constructed ideal as the everyday reality.

Everyday domestic material practices - their 'look', design and imagining -are especially pertinent to mid-twentieth century New Zealand. Along with many similar western countries, New Zealand was a society that was shot through with the key motif of domestic life and domestic desires. There was an emphasis on home pride at this time generally as part of the 'decent' family life and welfare of a broad kind. ${ }^{10} \mathrm{~A}$ State Advances Corporation leaflet (Figure 1) championing home ownership shows a woman in a sunhat and summer dress, talking to her husband who has one hand on a lawnmower and another holding a pipe, outside their home. Their daughter rides her 
tricycle on a path beside the house. It is an idyllic scene. On the left hand side of the pamphlet the reader is encouraged to ask for more information from the State Advances Corporation, established by the first Labour Government in 1939. The new government planned to use private enterprise to build 5000 state rental houses across New Zealand through a new Department of Housing Construction and the State Advances Corporation. By 1939 state houses were being completed at a rate of 57 per week in order to satisfy the 10,000 applicants on the state-house waiting list. The Second World War halted building until 1944, after which whole suburbs were planned and constructed. The government offered generous terms to encourage tenants to buy their state houses: a 5\% deposit, a state-provided mortgage with an interest rate of only 3\%, and 40 years to pay it back. Among the buyers were the first state-house family: the McGregors. They bought their home in 1952, declaring it their 'little piece of New Zealand'. ${ }^{11}$

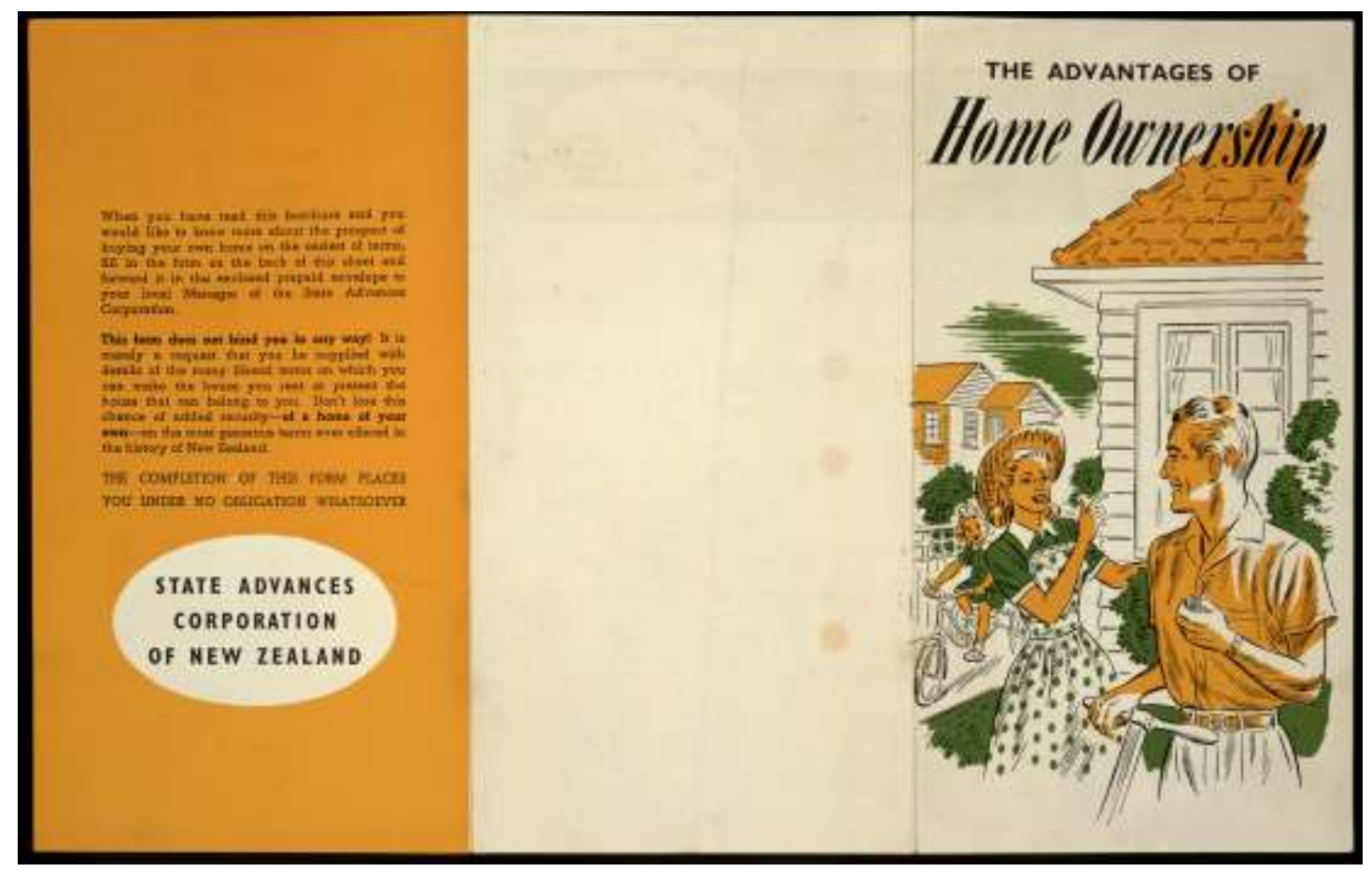

Figure 1: State Advances Corporation of New Zealand: The advantages of home ownership [Front and back cover. ca 1951]. Ref: Eph-A-HOUSING-1951-01-recto, Alexander Turnbull Library (ATL), Wellington, New Zealand. 


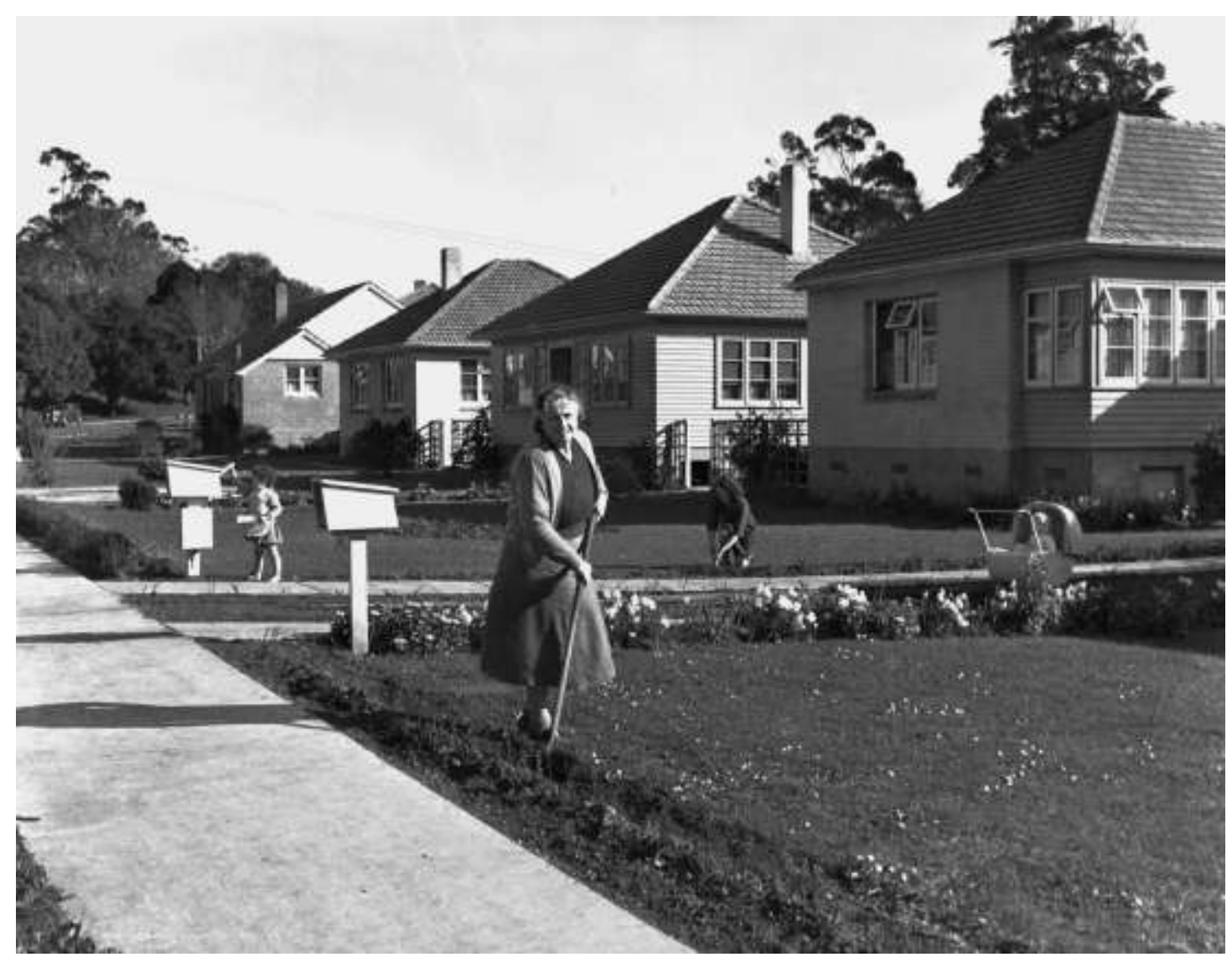

Figure 2: Keeping house and garden neat and tidy, Auckland, c.1950s. Sparrow Industrial Pictures Limited, Ref: Sparrow 2189a, Auckland War Memorial Museum Tamaki Paenga Hira.

This ideal and encouragement has been translated into reality, if a rather posed one, in Figure 2. A woman is hoeing her neat and tidy garden at the front of her Auckland state house in the 1950s, while a pram sits in the background. Further along a woman is gardening, while a young girl checks the letterbox. The properties are unfenced, because state-house areas were trying to encourage community and interaction, as if it was a garden suburb. Both images focus on the front garden and in the second the street and equally spic and span neighbourhood are included, reminding us of the importance of shared spaces and those in the view of others. The images show Pākehā living the good neighbourhood life and it was this good life that urbanizing Māori were encouraged to desire.

\section{Government frameworks}

Concern about neighbourly behaviour was articulated in the context of the diverse and complex relationships that emerged between Māori and Pākehā as part of the largescale and intensive migration of rural Māori to urban areas in the post war period. In 1926, only 9\% of Māori lived in cities and boroughs; in 1951 this figure was still only 19\%; but by the mid-1970s three-quarters of the Māori population lived in urban areas. This was one of the most rapid urbanizations of a population on record anywhere. ${ }^{12}$ It contrasts starkly with the continuing removal to reserves of Indigenous populations in parts of Australia, such as Queensland, and in North America and the internal or international migration of population groups, such as African Americans to northern 
cities in the United States, or West Indians to congregate in undifferentiated areas in Britain. ${ }^{13}$

From the point of view of the state, development of the Māori people as a whole was increasingly part of the migration process and the delivery of a wide range of welfare services that accompanied it. Well before the official policy of integration was outlined in the 1961 Hunn Report, such thinking was permeating official thinking. The 1945 Maori Social and Economic Advancement Act, for example, was 'designed to facilitate the full integration of the Māori race into the social and economic structure of the country'. ${ }^{14}$ Welfare in this sense was linked to the ability to be both a member and a successful inhabitant of Pākehā society, in the sense of integration and assimilation, but not necessarily cultural absorption. 'An important feature of the [1945] Act is that it does not seek to impose standards from without; rather it calls upon the Maori people to exercise control and direction of their own communities in the essentials of good citizenship and responsibility'. ${ }^{15}$ The definitions of 'integration', 'standards', 'good citizenship' and 'responsibility' were to baffle welfare officials, not to mention Māori families, as the case involving Mrs Fitchett shows when the Department's officers tried to carry out their role of promoting social change. Welfare officers nevertheless attempted to bring 'to the Maori the basic conditions of the pakeha social and economic structure'. ${ }^{16}$

Indeed, large-scale urbanization from the 1950s enabled Māori to achieve a higher standard of living and to take advantage of the material and educational benefits that Pākehā society offered. But it also brought new problems. Māori urbanization was perceived by contemporaries - particularly prejudiced neighbours, but also government officials and conservative Pākehā politicians - to be more problematic for family life and social order more generally. Some Māori also felt that urbanization led to cultural loss through separation from traditional lands and marae, and the further decline in the use of Māori language. ${ }^{17}$ As well as Māori families being simply more visible in the quickly expanding suburbs, from 1948 when Māori became eligible for state housing, the government instituted a policy of 'pepper-potting' Māori families by distributing them amongst Pākehā (often single Māori families in streets consisting entirely of Pākehā families) in order to avoid residential concentrations. ${ }^{18}$ This domestic metaphor in itself is striking and suggests how dilution of the black 'pepper' in white flour would make it not too obvious or conspicuous. In practice, however, the pepper did come to notice and was the cause of heated arguments. In Mrs Fitchett's case, the District Officer was extremely grateful to her for having brought these families to his notice.

Public anxiety about, and articulations of, 'Māori Problems' dominated official and popular discussions, especially after the publication of the Hunn Report in 1961. This report was 'one of the first systematic attempts to document the racial disadvantage of the Māori, and it presented this issue as a problem that had to be addressed by New Zealand society' ${ }^{19}$ It spelt out in chilling statistical appendices a range of measures - population, land settlement, housing, education, employment, health, land titles, legal differentiation, crime - which catalogued conspicuous disparity between Māori and Pākehā, and 'questioned the myth of racial equality' ${ }^{20}$ The Hunn Report recommended that race relations policy move beyond 'assimilation' to 'integration', whereby New Zealanders would become one people through the mixing of two cultures. The Hunn Report understood integration to mean: 'To combine (not fuse) the Maori and pakeha elements to form one nation wherein Maori culture remains distinct'. This was directly contrasted with assimilation which was 
defined as to 'become absorbed, blended, amalgamated, with complete loss of Maori culture'. ${ }^{21}$ Integration was adopted as government policy and in its very aim of mixing two cultures, rather than two becoming one culture, it significantly amplified the potential for interracial intimacy that was already in train. Propinquity was both maxim and practice. From 1960 the Māori Affairs Department ran an urban relocation programme encouraging Māori to leave rural areas for housing subdivisions at Ōtara, Māngare and Te Atatū in Auckland, as well as Porirua, the Hutt Valley and Wainuiomata in Wellington. State sponsored integration in the mushrooming suburbs was to be enacted through housing, garden and property design and the uses and maintenance of them. The visual and material cultures of post-war house and home both represented and produced a specific form of racial intimacy.

\section{Domesticity, modernity and culture}

For Māori, a 'good home' was increasingly recognised as 'the source of all social progress'. ${ }^{22}$ Not all Māori shared these aspirations initially, although more would do so; their collective and extended family social structures were at odds with this nuclear, individualistic focus. Because family itself meant something different for Māori, the goal of a good home also meant something different in this context. Unlike in other countries, where social work services inflicted change upon indigenous clients and children and families were deliberately dislocated, ${ }^{23}$ Māori welfare officers intervened in ways that made their work both acceptable and extremely useful to Māori, even though it invited greater scrutiny of those families.

As well as domestic life and desires, a second key motif of everyday domestic material and visual practices involved elevating Māori economically and socially in the context of modernity. Māori welfare officers and the Māori Affairs Department as a whole were directly and self-consciously concerned with 'race up lift'. This aim was predicated on proximity, especially in regard to houses and homes, so that Māori would live alongside Pākehā and learn how to live in the city and the suburbs. They would learn how to handle money and material goods and acquire all that a modern life and modernity could offer. Just as the 'civilizing effect of things became an integral part of the imperial project of commerce, Christianity, and civilisation, ... becoming used to more material possessions would habituate children to look after things and people and teach the domestic poor self-discipline and industry'. ${ }^{24} \mathrm{We}$ can see a similar motivation and set of practices in post-war New Zealand, albeit in a national rather than colonial context. This time race uplift was predicated not on close contact with missionaries and colonists, but with neighbours in the burgeoning suburb, and the acquisition of all the material comforts of modern life. 'Social progress', with its promise of 'modernity', signalled the wider goal of Māori adjustment to modern life and implicitly contrasted this with the traditional, rural village settlement and its extended living arrangements, which carried associations of poverty and crude living conditions (i.e. the opposite of modernity). ${ }^{25}$ As one 'lady' Māori welfare officer noted, Homes, homes and more homes is the general cry throughout the Dominion, for without homes we cannot educate our children from early childhood in the simple rules of hygiene. Only when our populace is adequately housed can we expect to compare with the pakeha. There are of course certain types of people who are content to live in hovels, and would make no honest efforts to better themselves, suggestions fall on deaf ears, the simple word "deposit" when referring to housing loans being sufficient to scare them away. Happily these types are rare. ${ }^{26}$ 
The Māori Affairs Department published a booklet Your New Home in 1954, which was given to owners of homes built by the Department. It reads: 'In simple story form this booklet will show the way a new home owner plans his home and grounds, furnishes, decorates, builds some simple improvements in the home, and meets his various new financial obligations, including some money laid by for future maintenance needs.' ${ }^{27}$ Home 'improvements', 'financial obligations' and future thinking, were all essential elements of modernity.

State houses for Māori emulated standard plans, with their two bedrooms, conjoined living and dining areas, kitchen and separate bathroom and toilet. A proliferation of housing plans went hand-in-hand with contemporary models of housing interiors in the crowded and ever more clamorous domestic visual and material culture of the period. Figure 3 features a smartly dressed woman in her gleaming modern and streamlined kitchen. The telephone is firmly ensconced in the kitchen, alongside the latest model refrigerator, stove, and the clean lines of the Formica bench tops and breakfast bar. The colour scheme, curtains and kitchenware are carefully selected and displayed. As Anne Else has recounted, 'I picked up the message very early, mainly from the pages of my mother's fat weekly bundle of magazines, showing fascinating floor plans of the right and wrong way to arrange furniture, or ten bright ideas for trimming lamp shades. ${ }^{28}$ 


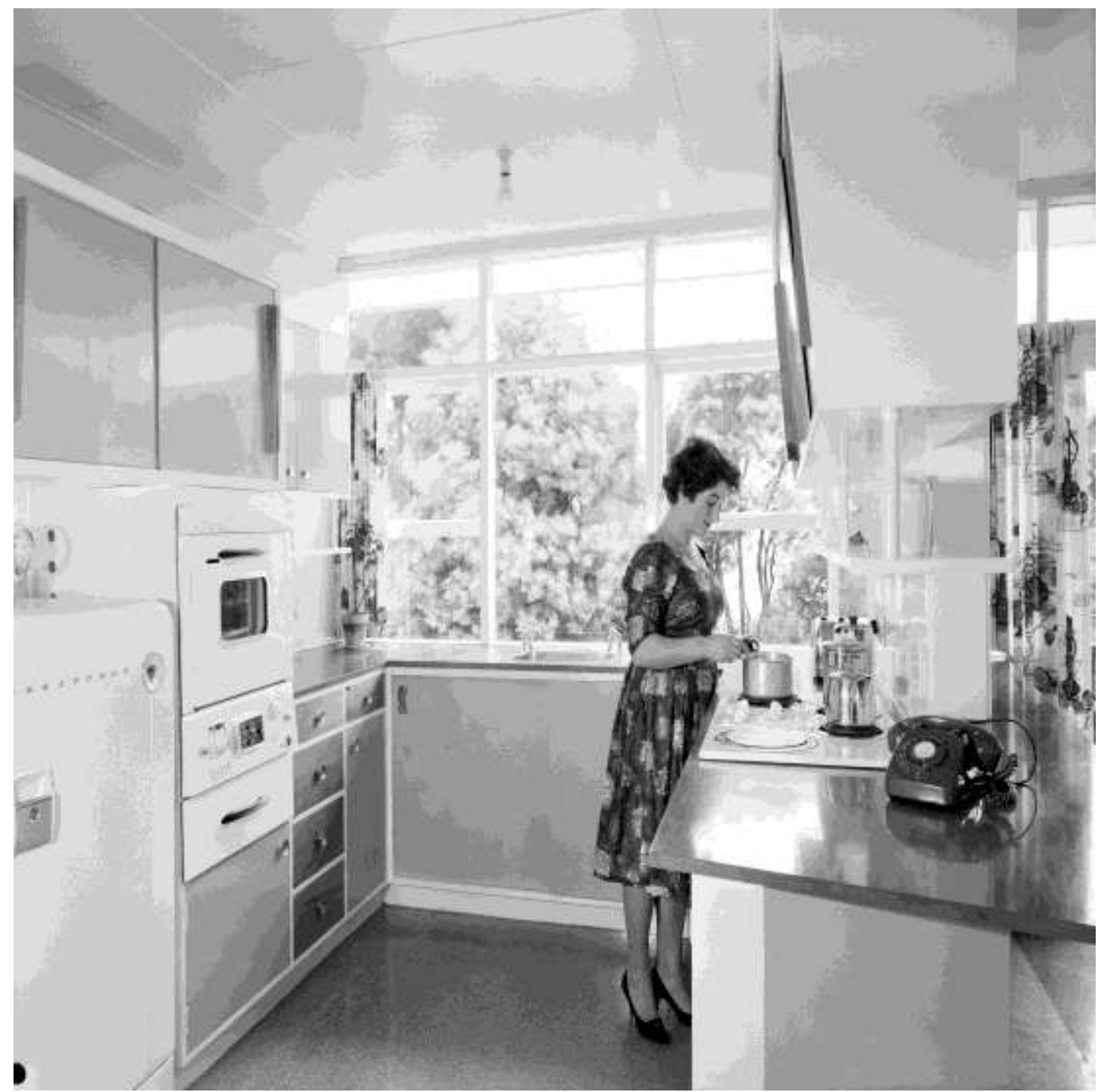

Figure 3: The kitchen in the Shuker House, Titahi Bay, Porirua, in the 1960s. Ref: DW-1045-F, ATL.

For Māori, there was a central repository for these exhortations aimed just at them. The DMA magazine Te Ao Hou ('The New World'), which described itself as a 'marae [meeting house] on paper', contained photographs, plans and detailed descriptions of welfare and financial assistance available, set alongside news items, extended journalism, poetry and literature. Published quarterly between 1952 and 1976, its content was similar to other popular magazine series such as The New Zealand Woman's Weekly. It contained advice on homecare, gardening and cooking and incorporated children's interests and community news. ${ }^{29}$ As such, it featured explicit commentary about domestic desires, race uplift and modernity, throughout stories and columns that set Pākehā standards as the norm. Te Ao Hou instructed its readers on housing design, and advised how to live a 'modern' life in the suburbs. The text accompanying Figure 4 reads:

An instance of homes built by the Government ten years ago for the Maori people. Pleasant and comfortable though this home is, it does not quite measure up to the design standards set today. Grounds and garden of this 
Northland homestead are in fine condition and typical of many Maori homes of this generation. ${ }^{30}$

The image is rural rather than suburban; the adjacent water tank and small size of the dwelling for the number of people shown outside it place it in an earlier era both figuratively, as well in the text, literally.

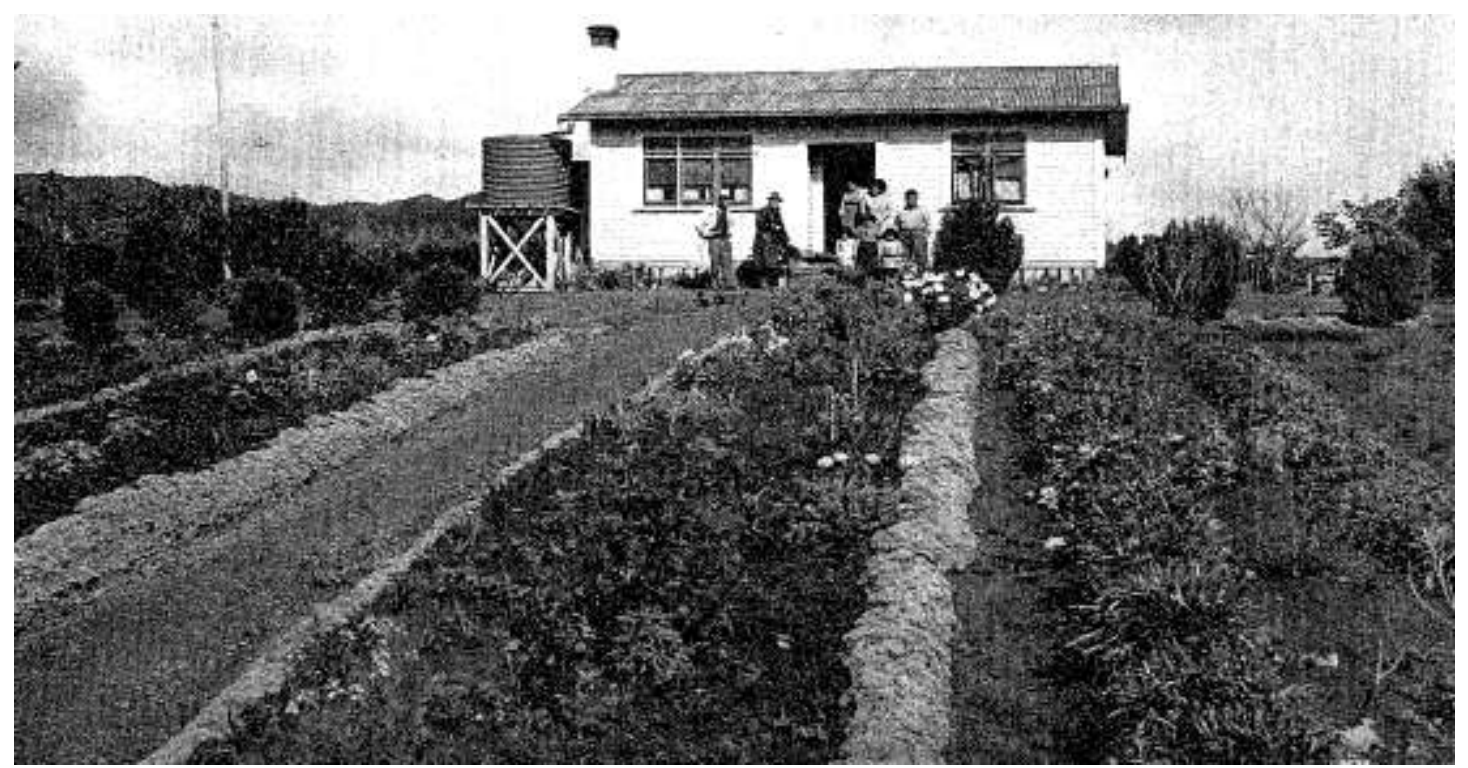

Figure 4: Te Ao Hou, no. 10, April 1955, p. 28. National Library of New Zealand Te Puna Mātauranga o Aotearoa. Permission to reproduce courtesy of the Māori Purposes Fund Board.
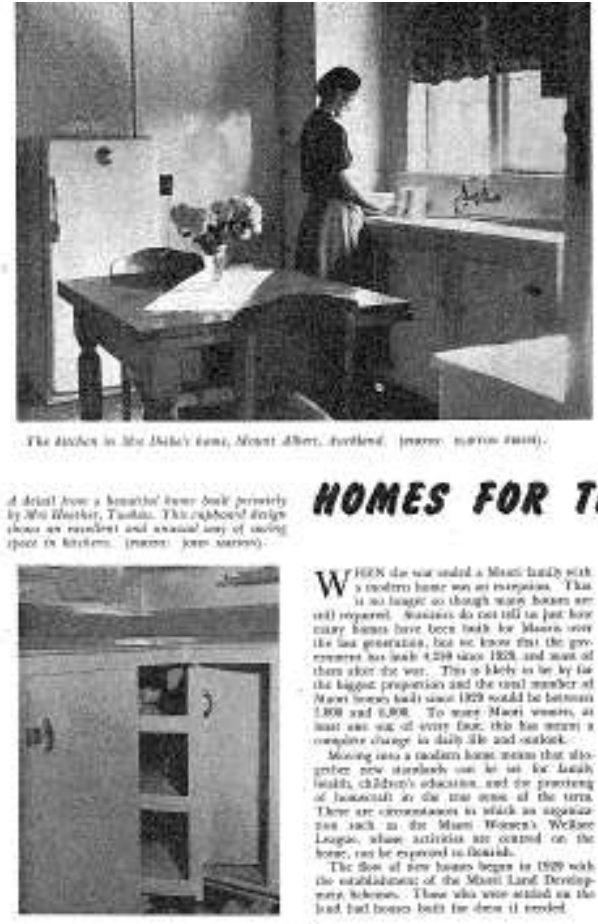

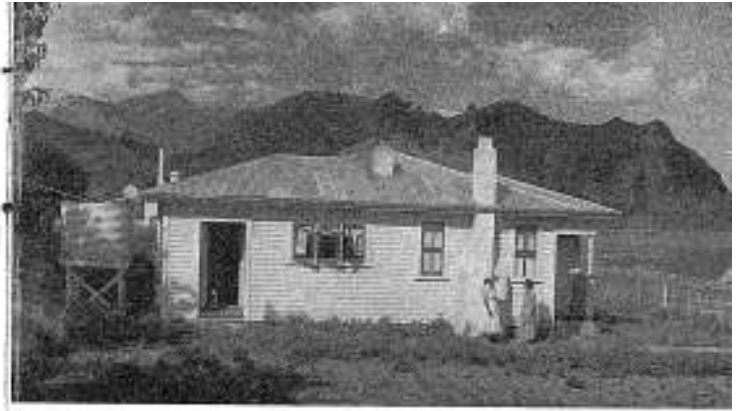

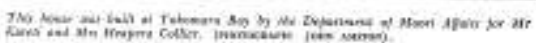

\section{MAORI PEOPLE}

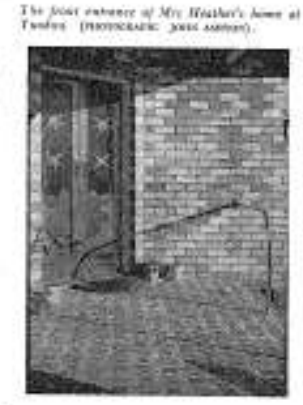


Figure 5: Images accompanying 'Homes for the Maori People', Te Ao Hou, no. 10, April 1955, pp. 26-27. National Library of New Zealand Te Puna Mātauranga o Aotearoa. Permission to reproduce courtesy of the Māori Purposes Fund Board.

Another article, 'Homes for the Maori People', accompanying Figure 5, advises that 'Moving into a modern home means that altogether new standards can be set for family health, children's education, and the practicing of homecraft in the true sense of the word ... An architect was put at the [Māori Affairs] department's disposal to gradually make design equal to the best for pakeha housing, ${ }^{31}$

The successive images in Figure 5 emulate the images from other mainstream sources: a woman in a modern kitchen with the latest appliances, the latest design elements and front entrance complete with sandblasted glass doors in the latest style. Didactic in tone, images were a central part of the contemporary imagining of suburban housing and it was accompanied by instruction in the material practices of modern, suburban life. This meant, for example, running water, electricity, a threebedroom home with windows, lino on the floor at least, if not carpet. It stood for a certain way of living but also for rational wage-earning achievement and aspiring values, and for improvement and material pride in an aesthetic sense. It also made clear that furnishing and decorating and 'caring' for home was a woman's task and responsibility. The role of the images in Te Ao Hou, accompanied and supported by the work of the Māori welfare officers, was to instruct families to live in the city. As DMA welfare officer Kuini Te Tau later recalled, 'all these people moving into their homes - didn't know what it was to pay rent or anything ... So we used to make them short pants and dress the kids and teach them to have a garden and what to grow'. ${ }^{32}$

As well as showing them in words and pictures what they should aspire to, there were other encouragements to modernize and be progressive in a manner suited to suburban life. ${ }^{33}$ DMA welfare officers supported the Māori Women's Welfare League's (MWWL) widespread 'best kept home and garden' competitions, and some suggested further competitions for the best-kept Māori home with an emphasis on grounds and exterior 'homecraft' ${ }^{34} \mathrm{Te}$ Ao Hou was again a vehicle for publicity and reinforcement. Figure 6 shows Mrs Paikea (left) and Mrs Penney (right) the joint winners out of 23 entries for the Northland competition. 'The aim was to encourage Maori people to garden and to take an interest in the appearance and general tidiness of their house surrounds'. ${ }^{35}$ 


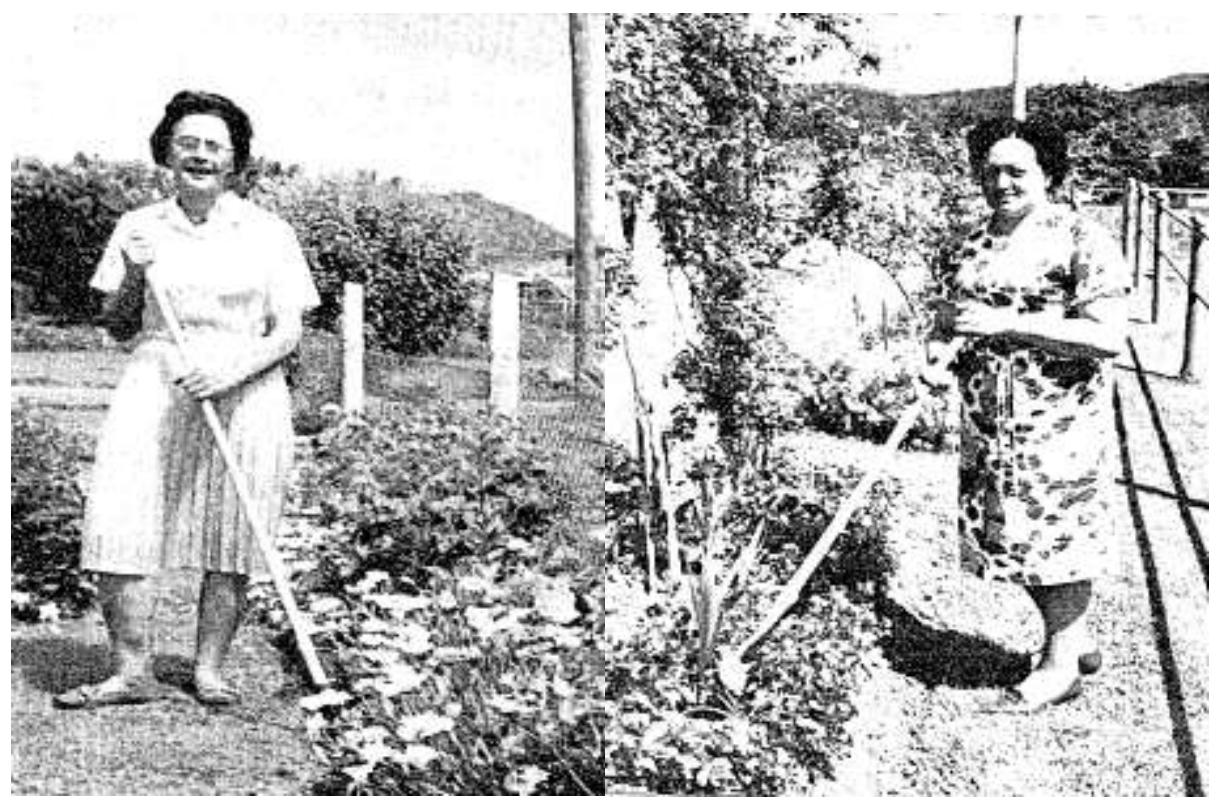

Figure 6: Mrs H. Paikea and Mrs J. Penny, joint winners of the Northland Garden Competition in 1966. Te Ao Hou, no. 58, March 1967, p. 40. National Library of New Zealand Te Puna Mātauranga o Aotearoa. Permission to reproduce courtesy of the Māori Purposes Fund Board.

The public outcry in 1964 over the Education Department's 'Washday at the Pa' booklet, featuring photographs by Ans Westra, is often discussed in the context of Māori aspirations in this period. Māori leaders, such as the MWWL accused the DMA of portraying a less than favourable image of Māori life. The booklet suggested through its depiction of a dwelling without electricity and hot water, that all Māori lived in sub-standard conditions and were happy to do so, that they were accustomed to a 'pre-modern' way of life, evoking the pā and all its perceived problems. The MWWL asked for the booklet to be withdrawn from circulation. But at the same time the MWWL was aiming to uphold the maintenance of traditional family roles, rights and obligations and 'traditional' Maori arts and crafts. There were tensions in the desire for 'modern' homes, between modernizing and defending or preserving existing practices. ${ }^{36}$ This tension can also be seen, albeit in a different way, in the way domestic aspirations were visualized and materialized for the booming suburbs, accompanied as they were by the policy of pepper-potting. As Michael Chan has noted: the examples in Te Ao Hou of the way the Department of Maori Affairs approached housing show that there was some concern over Maori culture with the shift to modern housing. It recognised that modern housing was compatible with the continuation of some forms of Maori culture. This idea was a key theme of Te Ao Hou's message of integration. The Department presumed that if most Maori and Pakeha owned clean and presentable homes then they would begin to possess corresponding values. It was a way to reduce tension and prevent conflict which could arise from the coexistence of divergent values. Although the magazine emphasised uniformity, it would frequently remind readers that a complete loss of Maori culture was not the intention. ${ }^{37}$

\section{Stresses and strains}


Tensions sometimes boiled over when Pākehā and Māori lived in close proximity, such as on the same street. The district Māori welfare officer at Auckland reported in 1957 that the numbers of families so housed that were giving trouble or had 'moral problems' amounted to only $7.5 \%$. He noted that this was a very low number and that the welfare staff had each problem case in hand. None of the families housed had problems involving the preservation of law and order, although police had been involved in three cases because of overcrowding or the need to ensure good behaviour. Many families had been re-housed on the grounds of over-crowding and decadent living conditions, with the support of the Health and Welfare Departments. According to the district officer, one of the reasons for problems with Māori housing was the colour bar or discrimination encountered when applying for rental houses or flats. As other historians have noted, there was a colour bar in jobs, the rental and real estate markets, while being served at hotels, with seating at cinemas, and even at hairdressers. ${ }^{38}$ Of those who had been housed by the Department, $92.5 \%$ were said to 'have been seized with their civic responsibilities' and were thus living 'up to normal European standards'. ${ }^{39}$ These responsibilities and standards were defined as living in a suburban home in a particular way; however, Māori used houses very differently to Pākehā, and living together in greater proximity brought these to the surface.

Pākehā complainants raised questions about how many people lived in Māori houses, the larger number of children present, and the larger gatherings in them for social occasions. Māori used their houses for a wider range of socializing, or personal relations, than the exhortation to see houses as vehicles for material enhancements and progress encouraged. For example, one family was visited by welfare officers because of their 'weakness for alcoholic drinking and their apparent disregard for those things that would help them in bettering their lot'. Their neighbours found the family was a nuisance, and claimed the parents and three children lived in 'unsatisfactory' conditions. The Māori welfare officer noted that they had been there for 12 months and had not shown 'any improvement in their personal possessions and code of living'. She believed that the children should be taken from their parents until they could prove they were fit to look after them. Yet the Pākehā senior child welfare officer, who also investigated this case, thought that despite the 'really appalling' conditions, Mrs Keith was making the best of the situation: the home was clean and tidy and the children looked well and were suitably dressed. ${ }^{40}$ For her, enforced interracial proximity was not the problem, but the poor conditions in which the family was forced to live. The Māori welfare officer was much more conscious of the family's failure to live up to expectations in the context of the push for integration.

Parties outside in the front garden, garish paint on the exterior of houses, using garages for funerals (tangi) in the absence of urban marae, were some of the many ways in which Pākehā found closer proximity with Māori uncomfortable and at odds with the contemporary cultural imagining of integration. Publicity in the print media about other instances of problematic behaviour did not help the reputation of Māori families, or efforts to share the street, and they stimulated further investigations. The complaints had become so frequent by 1961 that the Secretary of Māori Affairs wanted all reports about social behaviour, especially those relating to complaints from neighbours and other people, collated, analyzed by type and locality, and acted upon. ${ }^{41}$ Indeed, the Auckland district welfare officer feared that because the number of complaints was increasing to such an extent, there would be a large-scale breakdown in public relations, not only between Māori and Pākehā, but also between welfare officers and the complaining public. He was worried that 'the objectionable conduct of 
some Maori individuals and families would inevitably harden public opinion against the Maori people as a whole'. ${ }^{42}$ He had investigated some 25 cases and believed they would increase as more houses became available, that rural families moving to the city had a poor standard of 'social education', and that trouble between Māori and Pākehā neighbours was a cause of bad relations and likely to increase. Almost all of a random sample of 18 cases concerned parties, visitors, late hours, noise, bad language, fights, cars and trucks coming and going, children unattended and 'lack of consideration for the comfort of all those in the vicinity'. ${ }^{43}$ This was not about the standard of living in absolute material terms, but about 'social education' and consideration of the comfort of those nearby; it was about new forms of social relations and intimacy, and the very different uses of homes, housing and neighbourhoods.

In some cases where Māori families were investigated after complaints by Pākehā neighbours about, for example, 'wild parties' of up to 20 people in the house at one time and 'notorious in-laws', a full economic and domestic survey of the family was made, including details of the ownership of the house, the landlord's view, and a list of 'what efforts have been made in the past to bring this family up to scratch'. Enquiries about the roles of the tribal committee, the health inspector, the borough council, and child welfare were also made. Prohibition orders against those attending 'wild parties' were also considered. ${ }^{44}$ The welfare officer who was given these tasks noted, for example, that in one case Mr Reihana was 'not a bad sort of man, but he is easy-going and shiftless'. However, Reihana did not have the strength of character to keep his wife's nearest relatives out of their home. Mrs Reihana 'is only a fair housekeeper and although the house is not very clean it is not very dirty. The grounds are in much the same state'. The officer believed that if the house were in another area of Dannevirke, it would not stand out, but it happened to be in a very select area. The officer had 'long discussions' with Mr Reihana, warned the tribal committee that offensive behaviour would not be tolerated in this house or any other, and that $\mathrm{Mr}$ Reihana's house would be kept under observation. He concluded his report by saying that most Māori in the area were well behaved. ${ }^{45}$ The shifting standards - not very clean but also not very dirty - which differed according to suburb and emphasis on social type of behaviour are clear. One of the other fears that proximity brought to people like Mrs Fitchett and anxious Māori welfare officers was of dating, courting and sexual interaction. This would probably have been seen as exciting or normal to the younger people in the street, but perhaps not to their elders. ${ }^{46}$

A 1966 DMA booklet, Our Home, pressed new home owners to be aware of their responsibilities. The shift to 'our' rather than 'your' in the title was just one indication that the tone would be quite different from the 1954 edition. Readers were advised to be 'friendly and considerate, take pride in your home and surroundings ... it is useless to have a home and section in lovely order, the children neatly dressed, then spoil it all by having rowdy parties, especially late at night'. ${ }^{47}$

\section{Dealing with different migrants}

For neighbours of other newcomers to post-war suburban New Zealand, increased spatial, suburban, domestic proximity also led to misunderstandings, racial jibes and complaints, albeit of a more muted kind. Māori urbanization was of a far more intense pattern, yet for Chinese and Pacific Islanders, and even the more desirable English and Scottish migrants, cultural mixing was often problematic. Post-war New Zealand was monocultural and conformist, as migrants found out to their cost. English migrants were disappointed with New Zealand's obsession with rugby, early closing time at 
hotels, flimsy wooden houses on individual sections with gardens, and social separation of the sexes. Although reactions and interactions with British migrants appear to be less about 'race', there was a surprising hostility to 'Poms' (the slightly derogatory term used for British immigrants). People lodged complaints about the obnoxious deep-frying cooking habits of new 'Pommy' neighbours and there were other instances of neighbourhood misunderstandings and stand-offs. But English immigrants also knew that greater social inequalities and discrimination existed between Māori and Pākehā. ${ }^{48}$

The Dutch were by far the biggest single group of non-British immigrants to New Zealand at that time. The Dutch were also 'pepper-potted' up and down the country; it was feared that closed communities would result if they were allowed to cluster together. Language and accent, rather than appearance, singled them out. Up until the late 1970s, Dutch migrants faced immense pressure to 'blend in' to New Zealand society and forget their language and culture. Many Dutch were bewildered by life in New Zealand. They found typical Kiwi food such as pies and boiled mutton very strange, and real coffee was unheard of. Accustomed to European café society, they found the shop trading hours (closed all weekend) restrictive, and could not comprehend the 'six o'clock swill'. Women, because they were more often at home all day, particularly suffered isolation and homesickness. They found that 'the spirit of conviviality (gezelligheid), which is at the heart of Dutch culture, was in short supply'. Still, the Dutch were mostly seen as sensible and hard-working. ${ }^{49}$

Immigrants from the Pacific arrived in increasing numbers from the 1950s. Women came as domestic servants, and in the 1960s, men came as unskilled labourers for Auckland factories. Tapu Misa's family immigrated from Samoa in 1968. After living in several unsuitable inner-city houses in Wellington for the first year, they shifted out to nearby new suburb Porirua to a four-bedroomed state house, that was brand new, smelled of paint, and which sat on a bare, dirt section. They put themselves in debt for several years to buy a small fridge, a television and a lounge suite on hire purchase. They had no curtains for months and no carpets for years. Their only shops were a 30-minute bus ride away. Not many people had cars and most were in similarly low-paid jobs. Immigrant families fresh from Britain, Māori families and lots of Pacific Islanders were their neighbours. By this time state housing provision had significantly changed. The new mass-housing suburbs in Porirua and South Auckland were supposed to contain both state and private housing, but state housing was concentrated in particular areas. From the 1950s, the requirement for state housing to provide for the neediest created low-income communities, which included groups of urbanized Māori and Pacific Island peoples, who often experienced social problems associated with poverty and deprivation. This in turn altered the wider perception of state-housing communities from being sought-after places to live for the upperworking and middle-classes into becoming undesirable places. This shift was as much about class as it was about 'race'. Misa recounts how her grandmother found New Zealand suburban life bewildering and did not know how to engage in the required material practices. With everyone away all day at work and school she did not know how to use the oven. She washed her clothes by hand, as she did in Samoa, and spread them over the bushes and trees on the front and back garden because she did not know how to use the outdoor clothesline. ${ }^{50}$ It is no wonder that there were also complaints about Pacific Islanders in these new suburban spaces. Figure 7 shows the reality once housing stock became the province of poorer tenants with larger families. The houses are two-storied with little or no gardens, although an effort to make a wire fence is 
evident. It contrasts starkly with Figure 2. Yet the family lines up proudly for a photograph outside the house while a neighbouring child looks on.

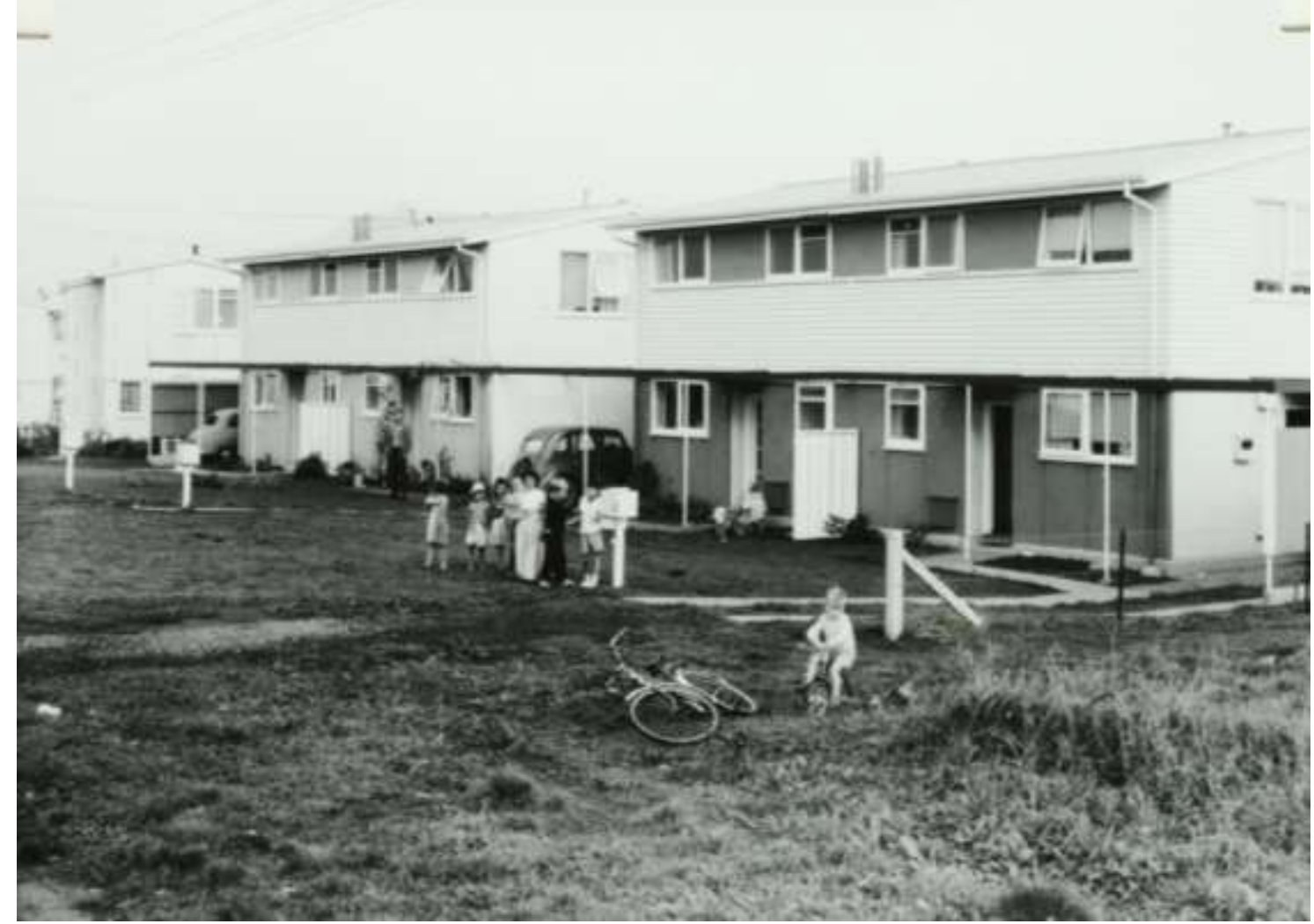

Figure 7: State housing in the Auckland suburb of Tāmaki, 1960. Re: AALF 7484 W3300, Box 10, Archives New Zealand Te Rua Mahara o Te Kāwanatanga, Wellington office.

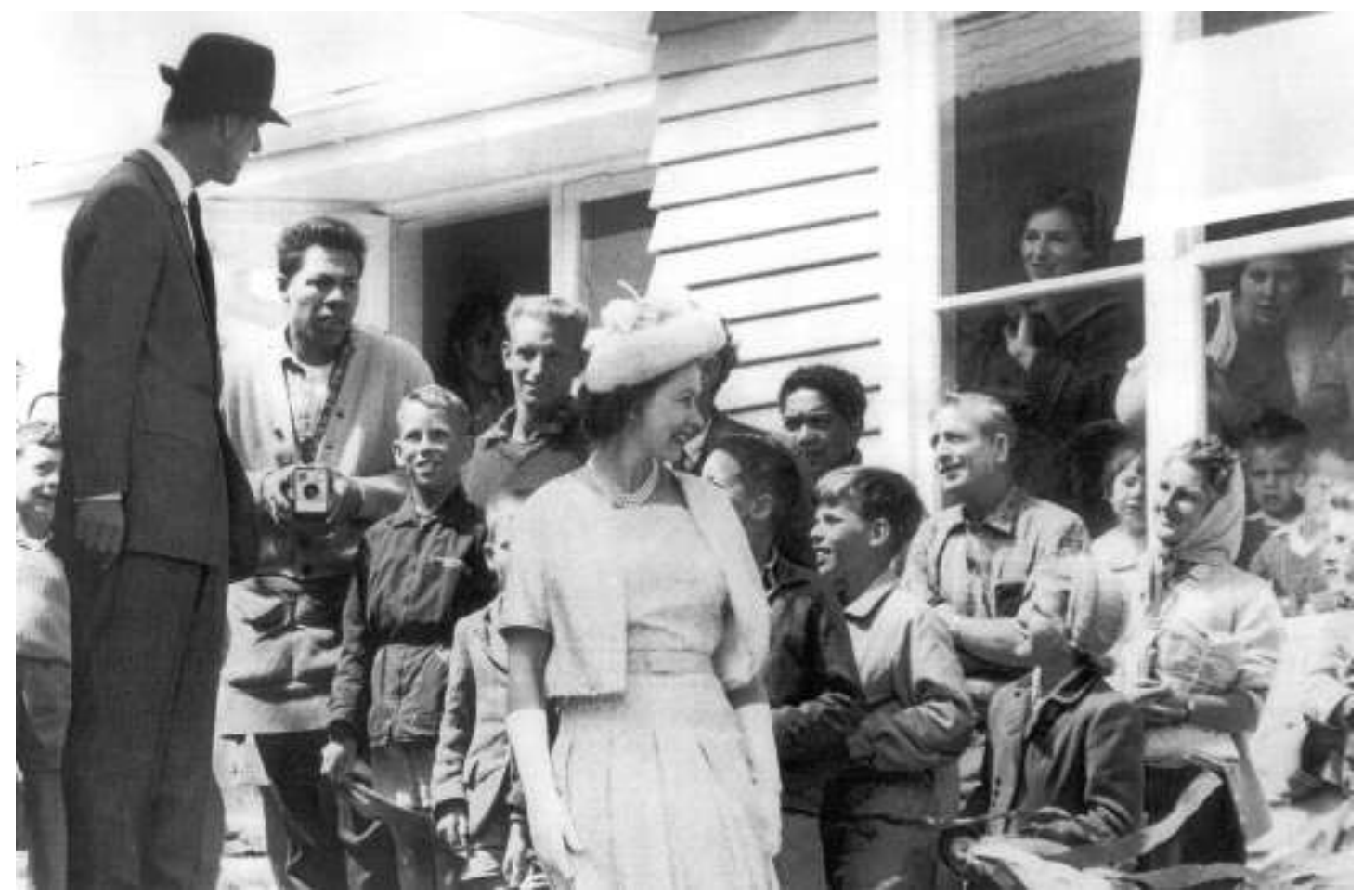


Figure 8: The Royal Couple visit the state housing suburb of Porirua East in Wellington, 1963. Private Collection.

In a further contrast, Figure 8 is resonant with these issues on many levels. Photographed informally by the builder of these state houses, Queen Elizabeth II and Prince Philip are on their 1963 royal visit to New Zealand, visiting Porirua East, an ethnically mixed, low-income suburb in Wellington and by then the largest state housing area in the country. The Royal couple were still at this time a model of the idealized family and here they are being crowded out by local Pacific Islanders, Māori and Pākehā families. The photograph is alive with all of the possibilities and tensions of neighbourly interracial intimacy of this era.

The growing diversity of post-war New Zealand, especially from the 1960s and 1970s is also evident in the experiences of the Chinese. Post-war immigration regulations continued to discriminate against Asian migrants. Despite this, the Chinese, who had lived in New Zealand from the early days of European settlement on the goldfields, had established communities in most urban centres. In 1947 the Government allowed the wives and families of long-time residents to join them in New Zealand. Many had been separated for 20 years or more. Chinese immigrants also lived in larger family groups, like Māori and Pacific Islanders. They too were looking for adequate housing and faced issues where proximity and propinquity has its awkwardnesses. There were, for example, complaints from a Pākehā family having to share a toilet and bathroom with a Chinese family in a state block of flats. This was seen as a sign of how desperate people were for suburban housing. Similarly, when Rosie Young and her Chinese family moved into a state house in the North Island town of Levin in 1950, local residents complained bitterly and the story was reported in the New Zealand Truth, the national tabloid newspaper which traded in scandalmongering. This led to the Chinese being very cautious: the tolerance of Pākehā New Zealanders was a privilege, not a right, which could be revoked at any time. ${ }^{51}$

These migrants were all in various ways under pressure to fit in during a time of changing patterns of immigration. The distinctive New Zealand pattern of interracial neighbourhoods meant that housing and the street were the social domains where this was played out and negotiated. The material and visual elements of new urban spaces of interracial intimacy in this period are captured in the historical record in revealing ways once you extend the range of sources consulted. Through photographic and pictorial imagery in $\mathrm{Te} \mathrm{Ao} \mathrm{Hou}$ and other contemporary sources, such as Department publications and publicity photographs, the 'practices of looking' around new urban spaces and housing are laid bare. Despite the policy of integration which was supposed to involve the mixing of two cultures, they reveal that the aim, if not the reality, was the Pākehā norm. Yet many of these sources have a necessarily static quality. They show structure and function, aspiration, desire and duty, but not always practice and process. The visual and material culture of this period constructed racial intimacy, as much as it reflected policy and experiences. It was not just a one-way process. Through the often didactic literature of government agencies, and the immediacy of personal recollections, we can sketch out the contours of how this was materialized, as I have shown here. This material culture was part of the package of practices to govern or manage the conduct of families who, in turn, saw themselves depicted in state discourse. 
Interracial proximity through state housing and 'pepper-potting' in suburban spaces in post-war New Zealand is also an instructive case study of how Māori and other 'races' used goods in changing patterns, to use Frank Trentmann's phrase. ${ }^{52}$ This case study reconnects private domesticity and public policy. It provides a bridge between histories of state policy and politics and histories of visual and material culture. It demonstrates how important an extended, neighbourhood-focused concept of 'intimacy' was to twentieth century New Zealand and how the notion of 'interracial' can also be extended fruitfully beyond its current predominant usage related to colonizers and indigenous. Post-war New Zealand involved sometimes desired, often forced intimacy at home and on the street, and the associated difficulties provide a key lens onto everyday life in this period.

I would like to thank the editors Rani Kerin and Angela Wanhalla, as well as Charlotte Macdonald, Kate Hunter and Margaret Tennant for their helpful comments and suggestions.

${ }^{1}$ District Officer to Acting Secretary, Maori Affairs, 14 December 1960, MA 1, 36/1, volume 9, Archives New Zealand (ANZ), Wellington.

${ }^{2}$ See for example, Elizabeth Vibert, "Writing "Home": Sibling Intimacy and Mobility in a Scottish Colonial Memoir', in Tony Ballantyne and Antoinette Burton, eds, Moving Subjects: Gender, Mobility, and Intimacy in an Age of Global Empire, Urbana, 2009, pp.67-68; Charlotte Macdonald, 'Intimacy of the Envelope: Fiction, Commerce, and Empire in the Correspondence of Friends Mary Taylor and Charlotte Bronte, c.1845-55', in Ballantyne and Burton, eds, Moving Subjects, pp.89-109; Kirsten McKenzie, 'Social Mobilities at the Cape of Good Hope: Lady Anne Barnard, Samuel Hudson, and the Opportunities of Empire, c.1797-1824', in Ballantyne and Burton, eds, Moving Subjects, pp.274-95.

${ }^{3}$ Graeme Dunstall, 'The Social Pattern', in G.W. Rice, ed., The Oxford History of New Zealand, Auckland, 1992, p.458.

${ }^{4}$ Influential works include: Ann Laura Stoler, Carnal Knowledge and Imperial Power: Race and the Intimate in Colonial Rule, Berkeley, 2002; Ann Laura Stoler, ed., Haunted By Empire: Geographies of Intimacy in North America, Durham, 2006; Katherine Ellinghaus, Taking Assimilation to Heart: Marriages of White Women and Indigenous Men in the United States and Australia, 1887-1937, Lincoln, 2006; Sarah Carter, The Importance of Being Monogamous: Marriage and Nation Building in Western Canada to 1915, Edmonton, 2008; Ballantyne and Burton, eds, Moving Subjects. See also Damon I. Salesa, Racial Crossings: Race, Intermarriage, and the Victorian British Empire, Oxford, 2011.

${ }^{5}$ Ballantyne and Burton, eds, Moving Subjects, p.4.

${ }^{6}$ Anna Haebich, 'Imagining Assimilation', Australian Historical Studies, 33, 118 (2002), pp.61-70.

${ }^{7}$ Ballantyne and Burton, eds, Moving Subjects, p.15. See also Vibert, p.68.

${ }^{8}$ Frank Trentmann, 'Materiality in the Future of History: Things, Practices, and Politics', Journal of British Studies, 48 (2009), p.289.

${ }^{9}$ Marita Sturken and Lisa Cartwright, Practices of Looking: An Introduction to Visual Culture, 2nd ed., New York, 2008.

${ }^{10}$ For a fuller discussion see Bronwyn Labrum, 'Persistent Needs and Expanding Desires: Pakeha Families and State Welfare in the Years of Prosperity', in Bronwyn 
Labrum and Bronwyn Dalley, eds, Fragments: New Zealand Social and Cultural History, Auckland, 2000, pp.188-210.

${ }^{11}$ Quoted in Ben Schrader, We Call it Home: A History of State Housing in New Zealand, Auckland, 2005, p.47.

${ }^{12}$ Ranginui Walker, 'The Maori People Since 1950', in The Oxford History of New Zealand, p.500; Dunstall, pp.455, 457; Ian Shirley, Peggy Koopman-Boyden, Ian Pool and Susan St John, 'New Zealand', in Sheila B. Kamerman and Alfred J. Kahn, eds, Family Change and Family Policies in Great Britain, Canada, New Zealand and the United States, Oxford, 1997, p.210.

${ }^{13}$ Mary Chamberlain, ed., Caribbean Migration: Globalised Identities, London, 1998; Bill Schwarz, ed., The Expansion of England: Race, Ethnicity and Cultural History, London, 1996; Wendy Webster, Imagining Home: Gender, 'Race' and National Identity, 1945-64, London, 2003.

${ }^{14}$ New Zealand Official Year Book (NZOYB), Wellington, 1953, p.951.

15 ibid.

${ }^{16}$ Appendices to the Journals of the House of Representatives (AJHR), 1954, G-9, p.5.

${ }^{17}$ For wider discussion of this phenomenon, see Megan C. Woods, 'Integrating the Nation: Gendering Maori Urbanisation and Integration, 1942-1969', PhD thesis, University of Canterbury, 2002; Aroha Harris, 'Dancing with the State: Maori Creative Energy and Policies of Integration, 1945-1967', PhD thesis, University of Auckland, 2007; Aroha Harris, 'Concurrent Narratives of Maori and Integration in the 1950s and 60s', Journal of New Zealand Studies, 6/7 (2007/2008), pp.139-55; Melissa Williams, "Back Home" and "Home in the City": Maori Migrations from Panguru to Auckland, 1930-1970', PhD thesis, University of Auckland, 2010.

18 'Pepper potting' was also instigated in New South Wales, Australia, when the Federal Department of Housing took over responsibility for housing from State Departments of Aboriginal Affairs. See Heather Goodall, Invasion to Embassy: Land and Aboriginal Politics in NSW, 1770-1972, St Leonards, 1996, p.332. Similar problems of urbanization and disruption to social order appeared in 1950s Victoria, Australia, which have been discussed by Corrine Manning, 'If Aborigines are to be assimilated they must learn to live in houses', in Tim Rowse, ed., Contesting Assimilation, Perth, 2005, pp.221-36. My thanks to Kate Hunter and Rani Kerin for alerting me to these references.

${ }^{19}$ Paul Spoonley, Racism and Ethnicity, Auckland, 1988, p.75.

${ }^{20}$ J. K. Hunn, Report on Department of Maori Affairs, Wellington, 1961, p.13; Spoonley, p.75.

${ }^{21}$ Michael Chan, 'Dawn and Te Ao Hou: Popular Perspectives on Assimilation and Integration, 1950s-1960s', BA (Hons) research essay, University of Otago, 2008, p.27. ${ }^{22}$ AJHR, 1948, G-9, p.1.

${ }^{23}$ Robert van Krieken, Children and the State: Social Control and the Formation of Australian Child Welfare, Sydney, 1991; Anna Haebich, Broken Circles:

Fragmenting Indigenous Families 1800-2000, Fremantle, 2000; Stuart Banner, How the Indians Lost their Land: Law and Power on the Frontier, Cambridge, 2005.

${ }^{24}$ Trentmann, pp.293-4.

${ }^{25}$ A point made by Barbara Brookes, 'Nostalgia for "Innocent Homely Pleasures": The 1964 New Zealand Controversy over Washday at the Pa', Gender and History, 9, 2 (1997), p.251.

${ }^{26}$ Phrasing as in original. Lady welfare officer's general report, Zones 2 \& 3, 1 April 
1951 - 31 March 1952, MA 1, 36/29/1, part 1, ANZ.

${ }^{27}$ AJHR, 1954, G-9, p.6.

${ }^{28}$ Cited in Labrum, 'Persistent needs and expanding desires', p.201.

${ }^{29}$ Chan, pp.4, 11.

${ }^{30}$ Te Ao Hou, no. 10, April 1955, p.28.

${ }^{31}$ ibid., p.26.

${ }^{32}$ Anna Rogers and Miria Simpson, eds, Early Stories from Founding Members of the Māori Women's Welfare League: Te tīmatanga tātau tātau, Te Rōpū Wāhine Màori

Toko i te Ora, Wellington, 1993, p.275. The Auckland Weekly was a local newspaper.

${ }^{33}$ See also Chan, pp.67, 77.

${ }^{34}$ District Officer, Rotorua, to Head Office, 2 August 1963, MA 1, 1/9/11, ANZ. The

Maori Women's Welfare League was established in 1951 and worked closely with the government. It focused on improving Māori housing, health, and education.

${ }^{35}$ Te Ao Hou, no. 58, March 1967, p.40.

${ }^{36}$ For an extended discussion see Brookes, 'Nostalgia for "Innocent Homely

Pleasures"'.

${ }^{37}$ Chan, p.79.

${ }^{38}$ See Redmer Yska, All Shook Up: The Flash Bodgie and the Rise of the New

Zealand Teenager in the Fifties, Auckland, 1993, pp.50-52; Angela Ballara, Proud to be White? A Survey of Pakeha Prejudice in New Zealand, Auckland, 1986, pp.98-103.

${ }^{39}$ District Welfare Officer, Auckland, to Secretary, Head Office, 8 July 1957, MA 1, 30/1/41, ANZ.

${ }^{40}$ Maori Welfare Officer to Under Secretary, Maori Affairs, 9 June 1949, Senior

Child Welfare Officer to Under Secretary, Maori Affairs, 6 July 1949, MA 1, 36/11, part 2, ANZ.

${ }^{41}$ Circular dated 29 May 1961, MA 1, 36/1, volume 9, ANZ.

42 'Social Problems' [1961], p.1, MA 1, 36/1, volume 9, ANZ.

43 'Social Problems' [1961], p.2, MA 1, 36/1, volume 9, ANZ.

${ }^{44}$ Controller to Maori Welfare Officer, Hastings, 13 February 1950, MA 1, 36/1, volume 4, ANZ.

${ }^{45}$ Maori Welfare Officer, Hastings to Controller, 15 February 1950, MA 1, 36/1, volume 4, ANZ.

${ }^{46}$ A 1952 feature film, Broken Barrier, focused on an interracial love story between a Māori woman and a Pākehā man. Rawi's mother worries about how living in the city will change her, as she pursues a nursing career, while Tom's family disapprove of Rawi, believing she will bring 'bad blood into the family'. Barbara Brookes argues that this was a genre movie and it was not a response to a pressing social issue. See Barbara Brookes, 'Cinema and the interpretation of 1950s history: John O'Shea and Roger Mirams, Broken Barrier (1952)', in Alistair Fox, Barry Keith Grant, and Hilary Radner, eds, New Zealand Cinema: Interpreting the Past, Chicago, 2011, pp.175-98.

${ }^{47}$ Department of Maori Affairs, Our Home, Wellington, 1966.

${ }^{48}$ Megan Hutching, Long Journey for Sevenpence: An Oral History of Assisted Immigration to New Zealand from the United Kingdom, 1947-1975, Wellington, 1999, p.157.

${ }^{49}$ Redmer Yska, 'Dutch - Migration after 1945', Te Ara - the Encyclopedia of New Zealand: http://www.TeAra.govt.nz/en/dutch/2-3.

${ }^{50}$ Tapu Misa, ‘An Immigrant's Tale', North and South, September 1987, pp.32-47. 
${ }^{51}$ Kirsten Wong, 'A Place to Stand: The Chun family Experience', in Manying Ip, ed., Unfolding History, Evolving Identity: The Chinese in New Zealand, Auckland, 2003, p. 129.

${ }^{52}$ Trentmann, p.289. 